\title{
A COMPARATIVE STUDY ON ANTICANCER EFFECT OF CRUDE VENOMS OF THE EGYPTIAN NAJA-HAJE AND VIPER CERASTESCERASTES ON HEAD AND NECK SQUAMOUS CELL CARCINOMA (IN VITRO STUDY)
}

\author{
Safa Fathy Abd El-Ghani * and Eman M. Amr ${ }^{* *}$
}

\begin{abstract}
Objectives This study aimed to examine and compare the anticancer effects and apoptotic potentials of both Najahaje (NH) and the horned viper Cerastescerastes $(\mathrm{CC})$ venoms on Head and neck squamous cell carcinomas (HNSCC) cell line.

Methods The effect of crude NH and CC venoms on larynx (Hep2) cancer cell line was investigated using MTT cytotoxicity assay, Cell cycle analysis by flow cytometry and Quantitative real-time PCR (qRT-PCR) analysis for caspase-3 expression.

Results venom treated groups $\mathrm{NH}$ and $\mathrm{CC}$ showed low IC50 values, decreased viability percentage of cancer cells, decreased percentage of DNA content in G0-G1 and S phases, increased percentage of DNA content in G2-M and pre G1 (total apoptosis) phases, increased percentage of cells in early and late apoptotic phases in addition to up-regulation of caspase-3 levels in comparison to negative control.
\end{abstract}

ConclusionThe present study clearly demonstrated high success rate of crude venoms of both Egyptian NH and CC and their promising efficacy against HNSCC cells, which highlights their possible anticancer effect and apoptotic potential Moreover, this study suggests the possibility of using $\mathrm{NH}$ and $\mathrm{CC}$ crude venoms as potential novel complementary or alternative therapies for HNSCC.

KEY WORDS: Naja-haje, Viper Cerastescerastes, apoptosis, Head and Neck Squamous Cell, apoptosis

\section{INTRODUCTION}

Head and neck squamous cell carcinomas (HNSCC) make up the vast majority (more than 90\%) of head and neck cancers and rank the sixth leading malignancy, worldwide (Sanderson \& Ironside, 2002 and Kamangar et al., 2006). They include a group of tumor entities arising from mucosal epithelium, and involving oral cavity,

*Associate Professor of Oral \& Maxillofacial Pathology, Faculty of Dentistry, Cairo University.

** Associate Professor of Oral Medicine, Diagnosis and Periodontology, Faculty of Dentistry, Cairo University. 
nasal cavity, paranasal sinuses, nasopharynx, oropharynx, hypopharynx, and larynx (Sturgis et al., 2007). However, HNSCC are often considered together because they share many similarities as aggressive behavior, high incidence of recurrence (5-7\% per year) as well as distant metastases and high mortality rate (Yan et al., 2011). According to GLOBOCAN (2018), HNSCC has accounted for 705,777 new cases and 358,144 deaths every year, globally (Bray et al., 2018). On the other hand, in Lower, Middle and Upper Egypt, they have accounted for about $1.19 \%, 2.17 \%$ and $4.77 \%$ of all cancers, respectively (Ibrahim et al., 2014).

Unfortunately, the conventional cancer treatments, Radio and chemotherapies, have been associated with severe morbidity due to involvement of vital structures, side effects and therapeutic resistance. That's why; there is a compelling need for novel alternative therapies for such a disease (Datema et al. 2010). A shift from using synthetic compounds to natural products introduced promising approaches in cancer chemotherapy (Demain and Vaishnav, 2011).Among these compounds, snake venoms are complex mixtures of proteins, peptides and bioactive molecules that may act as valuable resources for cancer drug development (Munawar et al., 2018).

Investigating the inhibitory effect of snake venoms on cancer cells dates back to the 1930s. Although they showed doubtful results at the early stages, recent studies offered ample evidence about their therapeutic potentials in treatment of cancer, especially through exerting cytotoxic, antiangiogenic and apoptotic effects (Li et al., 2018). In the past few decades, significant anti-cancer activity of crude snake venom and/or any of its fractions has been revealed in many cancer cell lines such as human breast cancer (Shebl et al., 2012; Akef et al., 2017), human hepatocellular carcinoma, human prostate carcinoma (Ebrahim et al., 2016), as well as, cervix adenocarcinoma, colon colorectal adenocarcinoma and bladder carcinoma (Ozverel et al., 2019). However, for the best of our knowledge, its effect on HNSCC has not been studied in the available literature.

The ancient Egyptian mythology showed a complex love-hate relationship with snakes representing both evil demons and goddesses. Several species of snakes inhabit Egypt's border. While most of them are harmless, Najahaje (NH) or the Egyptian cobra and the horned viper Cerastescerastes (CC) are deadly (Gouda et al., 2017). Previous studies on $\mathrm{NH}$ venom revealed its cytotoxicity and capability to induce apoptosis in a variety cancer cells (El Hakim et al., 2011; Al-Quraishy et al., 2014 and Tohamy et al., 2014). On the other hand, treatment of different cancer cell lines with $\mathrm{CC}$ venom showed that it served as apoptotic stimulator (Shebl et al., 2012), exerted inhibitory effect on angiogenesis, tumor cell adhesion and migration (ZouariKessentini et al., 2009 and Ben-Mabrouk et al., 2016) as well as cytotoxic and anti-proliferative effects (Akef et al., 2017 and Ozverel et al., 2019).

Accordingly, the aim of the present study was to examine and compare the anticancer effects and apoptotic potentials of both $\mathrm{NH}$ and $\mathrm{CC}$ venoms on HNSCC cell line, in an attempt to investigate the possibility of presenting these venoms as a possible novel therapeutic strategy for HNSCC.

\section{MATERIALS AND METHODS}

\section{Snakes' venoms}

Crude venom of NH $(250 \mathrm{mg})$ and CC (250 mg) were purchased from Egy Venom Company for scorpion and snakes venoms production for research and medical uses. Cairo, Egypt.

\section{Cell lines and culture conditions}

Larynx (Hep2) cancer cell line was purchased from Tissue Culture Department (VACSERAEgypt). It was cultured in Dulbecco's modified 
Eagle's medium (DMEM) supplemented with $10 \%$ heat inactivated fetal calf serum (FCS) and $\% 1$ penicillin-streptomycin then incubated at $37^{\circ} \mathrm{C}$ in a humidified atmosphere containing $\% 5 \mathrm{CO} 2$. Once semi-confluence (\%80-70 growth) was achieved, the growth medium was discarded from culture flasks, and PBS washing solution was added, followed by trypsin solution. Then cells were seeded in 96 well cell culture plates to desired seeding concentration ( $1 \mathrm{x} 10^{4}$ cells/well) to be ready for the viability assay (Akef et al., 2017).

\section{MTT cytotoxicity assay}

The MTT (3-(4, 5 Dimethylthiazol-2-yl) 2, 5 biphenyl tetrazolium bromide, a tetrazole) colorimetric method was conducted to assess cell viability in experimental venom-treated groups $(\mathrm{NH}$ and CC). After replacement of the media, $100 \mu \mathrm{L} /$ well of both examined venoms $\mathrm{NH}$ and $\mathrm{CC}$ was added and incubated for $24 \mathrm{~h}$, respectively with serial dilutions as presented in fig (1). These groups were compared to the control group (CG) which doesn't receive any treatment. This assay is used to evaluate the ability of living cancer cells to reduce MTT and form insoluble violet formazan crystals. A \%10 MTT solution $(5 \mathrm{mg} / \mathrm{mL})$ diluted in PBS was added to each well. The cultured cells were immediately incubated for 4 hours at ${ }^{\circ} 37 \mathrm{C}$ and protected from light until the presence of the violet formazan crystals was observed. For formazan crystals solubilization, $100 \mu \mathrm{L}$ of DMSO was added to each well. Later, the optical density (OD) was measured at a wavelength of $570 \mathrm{~nm}$ using ELISA plate reader. The cytotoxic dose of both venoms that were able to kill cancer cells by $50 \%$ (IC 50) was determined by using MASTER PLEX 2010 software. The cell viability percentage was then calculated using the following formula:

Cell viability $\%=$ Mean OD of Test Dilution / Mean OD of Negative Control X100 (Shebl et al., 2012).

\section{Cell cycle analysis by flow cytometry}

The effect of examined venoms $\mathrm{NH}$ and $\mathrm{CC}$ on cell proliferation and quantitative detection of apoptosis in venom-treated and control groups were assessed by measuring the distribution of cells in different phases of the cell cycle using Annexin-V/ Propidium Iodide (PI) dual staining assay. Hep2 cells were pre-cultured in $25 \mathrm{~cm}^{2}$ cell culture flasks and treated for 48 hours with the IC50 concentrations 47.6 and $25.32 \mu \mathrm{g} / \mathrm{ml}$ of $\mathrm{NH}$ and $\mathrm{CC}$, respectively in DMEM-media. Cells were then harvested by trypsinization, collected by centrifugation at 2000 rpm (for $10 \mathrm{~min}$ at $4{ }^{\circ} \mathrm{C}$ ), washed twice with icecold PBS fixed in $70 \%(\mathrm{v} / \mathrm{v})$ ethanol for at least 1 hour at $4^{\circ} \mathrm{C}$ for overnight.

After fixation, cells were stained by $50 \mu$ of Annexin V-FITC and $50 \mu$ of PI staining solution and diluted with binding buffer to a final volume of $500 \mu \mathrm{l}$ before flow cytometry analysis maintained at a temperature of $4^{\circ} \mathrm{C}$, and re-suspended in PBS containing $(0.1 \mathrm{mg} / \mathrm{ml} \mathrm{RNase})$ for $15 \mathrm{~min}$ in a dark room.Analysis was performed using Becton Dickinson (BD) fluorescence-activated cell sorting (FASC) calibre (Biosciences, flow cytometer, United States) with data displayed as frequency histograms and dot plots. Cells were analyzed for each sample through the different phases of cell cycle (G0-G1, S, G2-M) and the sub-G1 or apoptosis phases (early- late).

\section{Quantitative real-time PCR (qRT-PCR) analysis for caspase-3 expression}

Total RNA from venom-treated (NH \& CC) groups and untreated Hep2 cell lines (CG) was extracted with RNA extraction mixture "Gene JET RNA purification kit" according to the manufacturer's protocol. The RNA integrity and concentration were determined by measuring the optical density spectrophotometrically at 260 and $280 \mathrm{~nm}$. The extracted RNA was reverse transcribed to cDNA with Quantitect Reverse Transcription kit. cDNA was amplified for the expression of caspase-3 and GADPH with QuantiTect SYBR Green PCR kits according to the manufacturer's protocol. The sequence of primers used for Real-time PCR 
analysis were: Casp 3 F 5'-CTCGGTCTGGTACAGATGTCGA-3' and the Casp 3 R 5'-CATGGCTCAGAAGCACACAAAC-3' as well as GAPDH F 5'-GCA AGT TCA ACG GCA CGA TCA AG3' and GAPDH R 5'-CTA CTC AGC ACC AGC ATC ACC-3'.The relative quantification of caspase- 3 gene was determined using the comparative $\mathrm{CT}$ method. The $\Delta \mathrm{Ct}$ was calculated as the difference between the average $\mathrm{Ct}$ values of the GADPH from the average $\mathrm{Ct}$ value of caspase- 3 gene. The $\Delta \Delta \mathrm{Ct}$ was determined by subtracting the $\Delta \mathrm{Ct}$ of the control group from the $\Delta \mathrm{Ct}$ of both venom-treated groups $\mathrm{NH}$ and $\mathrm{CC}$. The thermal cycling profile consisted of $95^{\circ} \mathrm{C}$ for 10 minutes followed by 40 cycles of denaturation at $95^{\circ} \mathrm{C}$ for 30 seconds, annealing at $60^{\circ} \mathrm{C}$ for $1 \mathrm{~min}$. Samples were run in triplicate. Relative expression of the target gene was calculated by the equation $2^{-\Delta \Delta \mathrm{Ct}}$, which was the amount of caspase- 3 product, normalized to the endogenous control (GAPDH) and relative to the control sample (Mitupatum et al., 2016).

\section{Statistical analysis}

All experiments were carried out in three independent tests. Data were expressed as the mean \pm standard deviation (SD)for statistical evaluation. One-way analysis of variance (ANOVA) was used for comparing the 3 study groups: $\mathrm{CG}, \mathrm{NH}$ and $\mathrm{CC}$, followed by Post Hoc test for multiple pair wise comparisons. Results were considered statistically significant at probability $<0.05$.

\section{RESULTS}

\section{Viability Percentage}

Both $\mathrm{NH}$ and $\mathrm{CC}$ venoms showed relatively low IC50 values with $\mathrm{NH}$ showing a higher value of 47.6 $\mu \mathrm{g} / \mathrm{ml}$ than CC with a value of $25.32 \mu \mathrm{g} / \mathrm{ml}$ (fig. 4). In comparison to the untreated control group (CG), a gradual reduction in the viability percentage of cancer cells was observed in venom-treated groups with increasing doses of both venoms NH and CC. The values were plotted as shown in fig (1).



Fig (1): Graph showing viability $\%$ of the treated study groups (NH \& CC) with different venoms' concentrations

\section{Cell cycle analysis}

Concerning the control group, it showed high percentage of DNA content of the cancer cells in both G0-G1 and S phases, which reached 47.63 and 44.29 , respectively. Then a drop in the percentage was observed in G2-M phase (8.08\%). Contrarily, a marked inhibition in the DNA content of cancer cells entering the cell cycle in the venom-treated groups was observed in both G0-G1 (NH: $22.62 \%$ \& CC: $18.67 \%$ ) and $\mathrm{S}$ phases (NH: $29.58 \%$ \& CC: $27.59 \%$ ). On the contrary, in the pre-G1 and G2-M phases, a marked increase was detected in both venom-treated groups, where it reached up to sixfold higher than the control group in G2-M phase. All these data are represented in table (1), DNA histograms (fig 2) and column chart (fig 5).

Analysis of the venom-treated cancer cell line (NH and CC) groups showed marked increase in the percentage of total apoptosis which exceeded that of the control group by about ten to twelve folds. The highest percentage was detected in the $\mathrm{CC}$ group (36.41) followed by NH group (23.89). Dot plot representation of flow cytometric analysis showed that most of cells in all study groups located in the first quadrant as they were viable. An increase in percentage of cells in early apoptotic phase (located in second quadrant) was observed in $\mathrm{NH}(7.86 \%)$, and $\mathrm{CC}(7.25 \%)$ groups. On the other hand, a higher 
increase in percentage of cells in late apoptotic phase (located in third quadrant) was observed; where CC group (24.24\%) showed double that of $\mathrm{NH}(12.91 \%)$. Necrotic cells (located in fourth quadrant) were also detected in all study groups, with the highest percentage in CC $(4.92 \%)$ followed by $\mathrm{NH}(3.12 \%)$ (Figs 3,6).

\section{Caspase-3 levels}

Levels of caspase-3 were nearly undetectable in the control group. On the contrary, both venomtreated groups $\mathrm{NH}$ and $\mathrm{CC}$ showed high levels of caspase-3, which reached 19.16 and 26.76, respectively. The highest levels were seen in the
CC group. The values were shown in table (1) and column chart (Fig. 7).

\section{Statistical analysis}

A high statistically significant difference was obtained from all investigations of the current study: percentage of DNA content in different cell cycle phases (Pre-G1, G0-G1 and G2-M), total, early, late apoptosis and levels of caspase-3. Almost all pair wise comparisons showed statistically significant difference, except DNA content in S phase and percentage of cells in early apoptosis in venom treated $\mathrm{NH}$ versus $\mathrm{CC}$ groups. These data are represented in table (1) and figs (4-7).

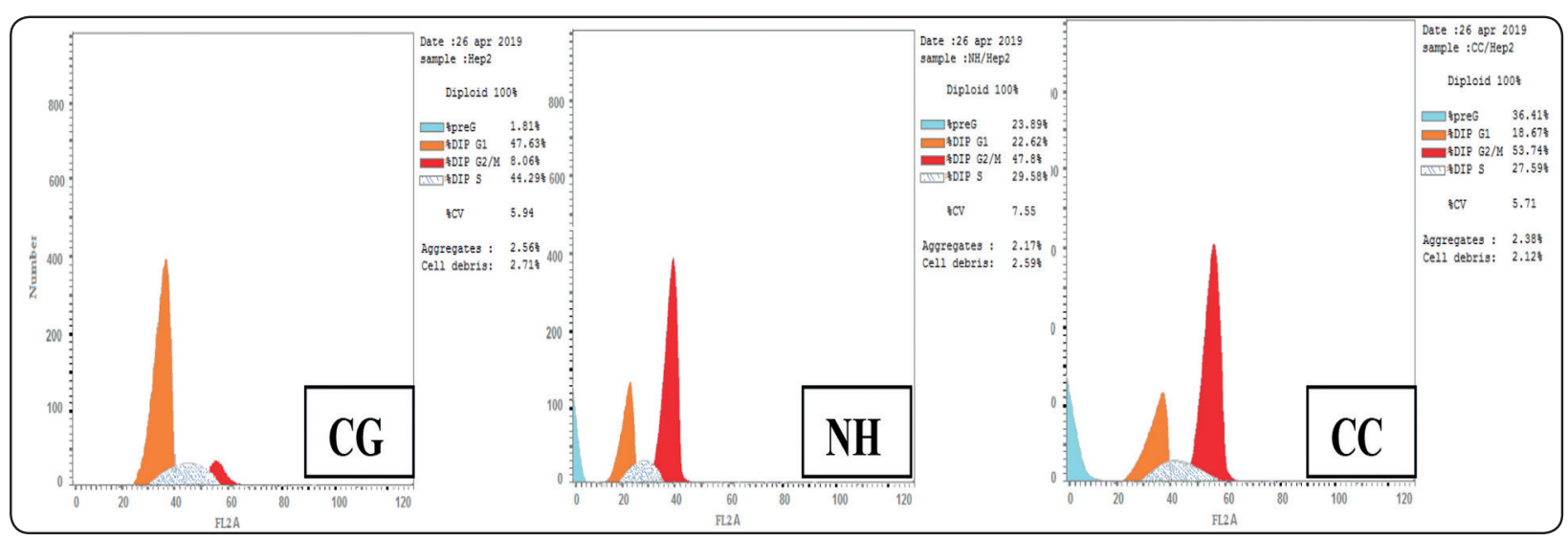

Fig, (2): DNA histograms showing decrease in DNA content in G0-G1 and S phases as well as increase in pre-G1 and G2-M phases of the venom-treated study ( $\mathrm{NH} \& \mathrm{CC}$ ) groups in comparison to untreated $\mathrm{CG}$.

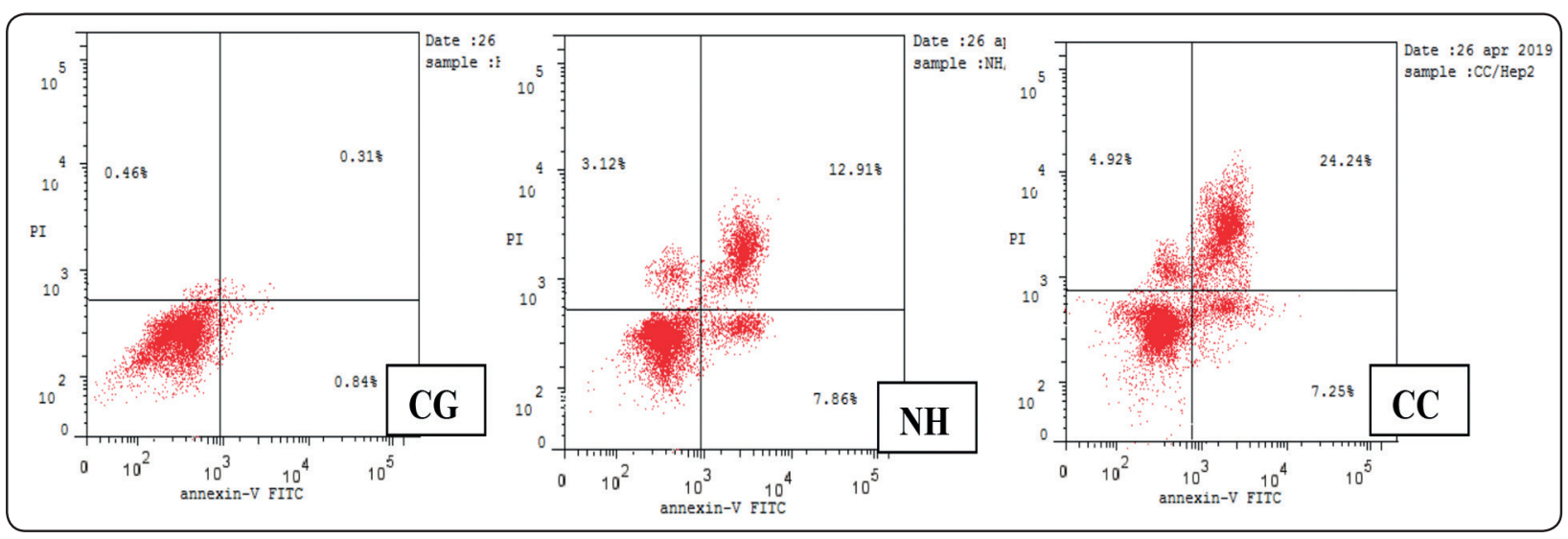

Fig. (3): Dot plots representation showing that most of cells are viable in all groups (CG, NH, CC), however, necrotic cells are seen. Percentage of cells has increased in early apoptotic phase in NH and CC groups. Late apoptotic phase has showed higher increase in percentage of cells in CC group followed by $\mathrm{NH}$ group. 
TABLE (1): Values of different investigations in venom-treated groups as well as negative control group (CG)

\begin{tabular}{|c|c|c|c|c|c|}
\hline \multicolumn{2}{|c|}{ Groups } & CG & NH & $\mathrm{CC}$ & P-value \\
\hline \multicolumn{2}{|c|}{ IC50 } & & 47.6 & 25.32 & \\
\hline \multirow{4}{*}{$\begin{array}{l}\text { Analysis of cell } \\
\text { cycle phases } \\
\text { (DNA content) }\end{array}$} & \%G0-G1 & $47.63 \pm 1.15^{\mathrm{a}}$ & $18.67 \pm 1.54^{\mathrm{b}}$ & $22.62 \pm 1.60^{\mathrm{c}}$ & $<0.001 * *$ \\
\hline & $\% \mathrm{~S}$ & $44.29 \pm 0.732^{\mathrm{a}}$ & $29.58 \pm 0.920^{\mathrm{b}}$ & $27.59 \pm 1.33^{\mathrm{b}}$ & $<0.001 * *$ \\
\hline & $\%$ G2-M & $8.08 \pm 0.617^{\mathrm{c}}$ & $47.8 \pm 1.61^{\mathrm{b}}$ & $53.74 \pm 1.09^{\mathrm{a}}$ & $<0.001 * *$ \\
\hline & $\begin{array}{c}\text { \% Pre-G1 } \\
\text { (total apoptosis) }\end{array}$ & $1.81 \pm 0.660^{c}$ & $23.89 \pm 1.12^{\mathrm{b}}$ & $36.41 \pm 0.544^{\mathrm{a}}$ & $<0.001 * *$ \\
\hline \multicolumn{2}{|c|}{ Early apoptosis } & $0.84000 \pm 0.314^{\mathrm{b}}$ & $7.8600 \pm 0.609^{\mathrm{a}}$ & $7.2500 \pm 0.397^{\mathrm{a}}$ & $<0.001 * *$ \\
\hline \multicolumn{2}{|c|}{ Late apoptosis } & $0.51000 \pm 0.128^{c}$ & $12.910 \pm 0.637^{\mathrm{b}}$ & $24.240 \pm 0.498^{\mathrm{a}}$ & $<0.001 * *$ \\
\hline \multicolumn{2}{|c|}{ Caspase-3 } & $1 \pm 0.214^{\mathrm{c}}$ & $19.17 \pm 0.524^{\mathrm{b}}$ & $26.76 \pm 1.39^{\mathrm{a}}$ & $<0.001 * *$ \\
\hline
\end{tabular}

In each row, superscripts with different letters are statistically significant, while superscripts with same letters are statistically non-significant (while a represents the highest values, $c$ represents the lowest ones)

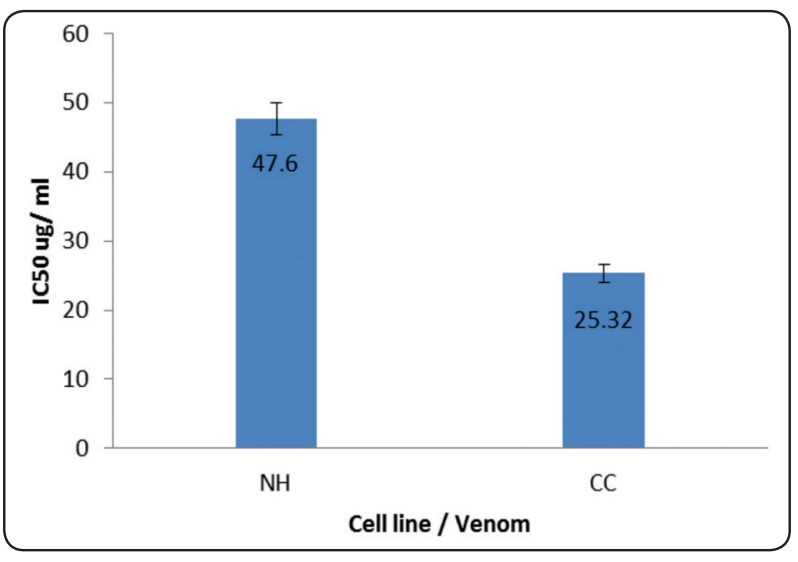

Fig (4): Column chart showing the IC50 values of both NH \& $\mathrm{CC}$ venoms

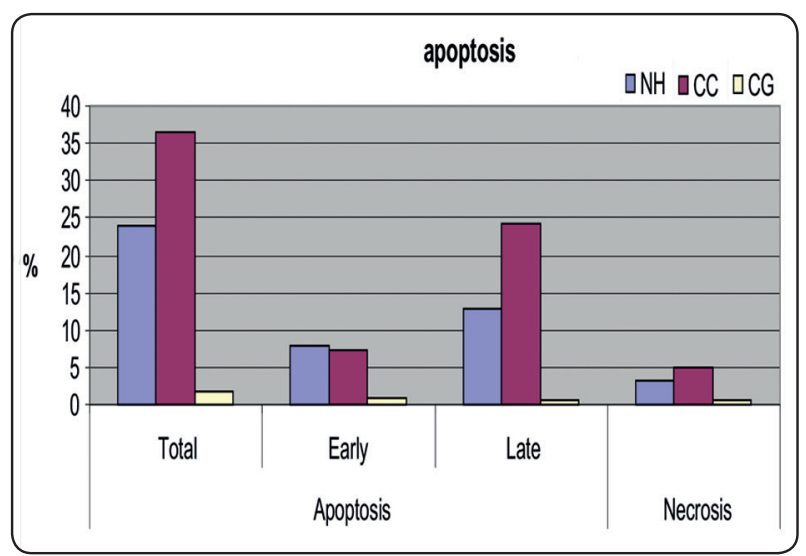

Fig (6): Column chart showing percentage of cells undergoing apoptosis in the venom-treated $(\mathrm{NH} \& \mathrm{CC}$ ) groups as well as untreated CG

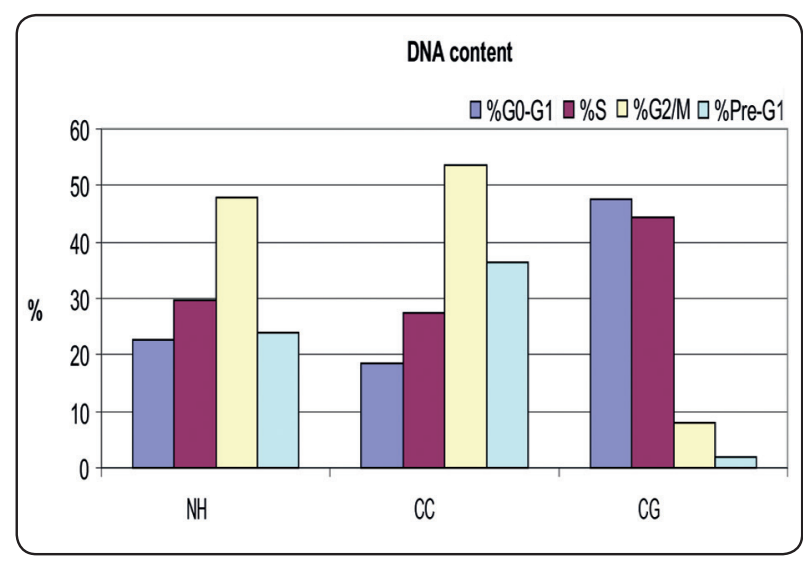

Fig (5): Column chart showing percentage of DNA content in different cell cycle phases in the venom-treated study (NH \& CC) groups as well as untreated control group

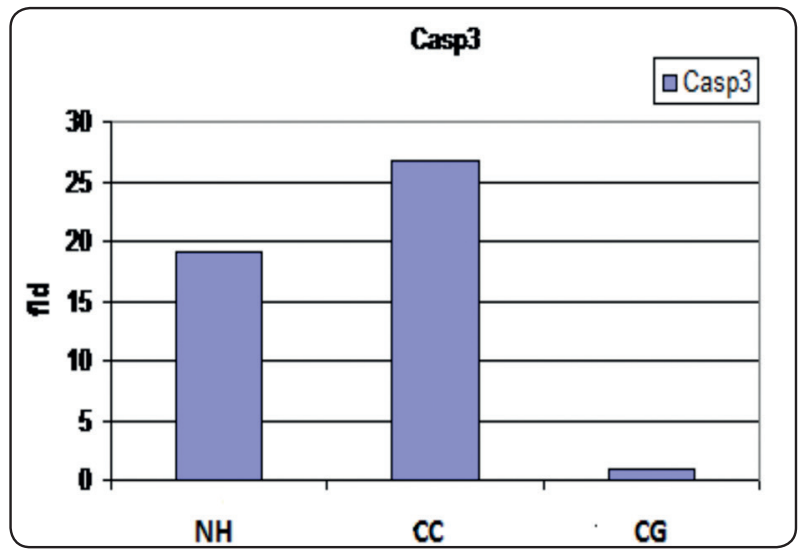

Fig (7): Column chart showing caspase-3 levels in the venomtreated (NH \& $\mathrm{CC})$ groups as well as untreated CG. 


\section{DISCUSSION}

Snake venoms are considered as a potential resource of biologically active compounds and they are well recognized in therapy of chronic diseases, including cancer (Li et al., 2018). Despite significant progress and tremendous advancement in cancer therapy, it remains one of the leading causes of death, worldwide (Shebl et al., 2012). Therefore, using snake venoms as a novel treatment modality could open a new era in the field of cancer treatment, especially because they are easy to synthesize and less prone to induce an immune response (Al-Asmari et al., 2016 and Munawar et al., 2018).

Keeping in view the importance of snake venoms, we investigated and compared the effects of two snake venoms of species inhabiting the Egyptian deserts, namely $\mathrm{NH}$ and CC on HNSCC cell line, using state of the art techniques: MTT assay, flow cytometry and RT-PCR. Regarding flow cytometry, it has allowed the identification and quantification of apoptotic cells as well as interpretation of cell cycle progression and apoptotic phases, as it offers rapid and accurate measurement of individual cells in large cell populations (Darzynkiewicz et al., 2010). Concerning RT-PCR, its increased sensitivity and specificity renders it a favorable option for quantitative analysis of cancer markers even the low copy targets (Valasek and Repa, 2005)

Results of the present study revealed potential cytotoxic effect of both $\mathrm{NH}$ and $\mathrm{CC}$ venoms on HNSCC in a dose-dependent manneras they succeeded to decrease the percentage of viable cells with increasing their doses.Moreover, both venoms showed relatively low IC50 values. In agreement with our results, Kakanj et al. (2015), Bradshaw et al. (2016), Ebrahim et al. (2016), Nalbantsoy et al. (2017) elucidated the cytotoxic effects of different snake crude venoms and various purified proteins on human cancerous cell lines. Similarly, Akef et al. (2017) and Ozverel et al. (2019) pointed out the cytotoxic effect of CC venoms.
The remarkable decrease in the percentage of HNSCC cells in the G0-G1 and S phases of cell cycle in the current work indicates that both venoms induced changes in the DNA content of cancer cells entering the cell cycle, leading to deregulated cell cycle and inhibition of cancer cell growth and proliferation. This reflects the capability of $\mathrm{NH}$ and $\mathrm{CC}$ venoms to inhibit cancer cell proliferation. In accordance to our findings Akef et al. (2017) revealed the anti-proliferative effect of $\mathrm{CC}$ venom. In the same context, Calderon et al. (2014) reported that other snake venoms such as Najanigricollis and Crotalusadamanteus were able to prevent cell proliferation and inhibited tumor growth via nigexine and crotalase, respectively.

On the other hand, the increase in percentage of cancer cells in G2-M phase indicates that both $\mathrm{NH}$ and $\mathrm{CC}$ venoms have caused irreparable DNA damage, which led to cell cycle arrest and accumulation of cells in this phase of cell cycle in preparation to apoptosis. In the same context, Long et al. (2017) explained that cell cycle arrest has been one of the major mechanisms associated with anti-tumor drugs. They added that many cancer cells were arrested at the G2-M checkpoint, due to defective G1 checkpoint during cell replication. This is further supported by the highly significant increase of percentage of cells in late apoptosis rather than early apoptosis in the current study. In contradiction to our results, Ebrahim et al. (2016) found out that snake venom was capable to induce G0-G1 arrest and promoted the S-phase fraction.

In authors' perspective, evaluation of the apoptotic potential of the candidate venoms shows extreme importance as evading apoptosis is one of the hallmarks of cancer, which leads to uncontrolled proliferation resulting in tumor survival, therapeutic resistance and recurrence as agreed by Fouad $\boldsymbol{\&}$ Aanei, 2017. Moreover, resistance to chemotherapy which is a major obstacle in cancer therapy, frequently prevents cancer cells from undergoing apoptosis with subsequent tumor cell survival and failure of treatment (Wilson et al., 2009). Hence, 
introducing a novel treatment modality that has an apoptotic potential seems very interesting.

Accordingly, detection of caspases' activation was accomplished in the current work, namely caspase-3, the main effector caspase, was used as an indicator of activation or down regulation of the mitochondrial pathway of apoptosis (Wlodkowic et al., 2012). In the present study, levels of caspase-3 were markedly elevated in association with both venoms in comparison to the control group, which indicates an active process of apoptosis via activation of caspase- 3 through the mitochondrial pathway. In agreement with our results, induction of mitochondrial apoptosis pathway and overexpression of caspase-3 in comparison to untreated groups were revealed with $\mathrm{NH}$ venom (El Hakim et al., 2011 and Al-Quraishy et al., 2014), CC venom (Shebl et al., 2012) in addition to other different snake venoms (Al-Asmari et al., 2016 and Ebrahim et al., 2016).

Induction of apoptosis was further confirmed by flow cytometric analysis where the percentage of early and late apoptotic cells has increased in $\mathrm{NH}$ and $\mathrm{CC}$ groups compared to $\mathrm{CG}$ group. In early stages of apoptosis, the plasma membrane loses symmetry causing phosphatidylserine (PS) to be translocated from cytoplasmic to outer surface of the plasma membrane and binds to Annexin-V, however during late apoptosis, disintegration of cell membrane takes place allowing PI to enter the cells and binds to DNA (Annexin-V and PI positive). Contrarily, mostcells in all groups were viable as they remained unstained (no PS exposure; no Annexin V labelling; no PI staining). On the other hand, necrotic cells has stained positive for PI due to membrane disintegration and to a certain extent also for Annexin $\mathrm{V}$ due to PS detection on intracellular side of the membrane (Shebl et al., 2012 and Wlodkowic et al., 2012).

It's worth noting that although the results of $\mathrm{NH}$ are in line with those of $\mathrm{CC}$, the later has shown more favorable results than those of $\mathrm{NH}$ group with a highly significant difference in almost all investigations, such as lower IC50 value, increased percentage of DNA content in G2-M and pre G1 (total apoptosis), increased percentage of cells in early and late apoptotic phases in addition to higher levels of caspase-3. This reflects that CC has exhibited a superior and more potent anticancer effect and apoptotic potential. In the same context, other studies showed the capability of $\mathrm{CC}$ venom to inhibit cancerous cell adhesion and migration as well as angiogenesis (Zouari-Kessentini et al., 2009 and Ben-Mabrouk et al., 2016). However, the more favorable anticancer effect of $\mathrm{CC}$ than $\mathrm{NH}$ venoms was not reported before, as for the best of our knowledge, this is the first study to compare the anticancer effects of both venoms on HNSCC.

In conclusion, the present study clearly demonstrated high success rate of crude venoms of both Egyptian NH and $\mathrm{CC}$ and their promising efficacy against HNSCC cells. The present data highlights the possible anticancer effect and apoptotic potential of the candidate venoms. Moreover, this study suggests the possibility of using $\mathrm{NH}$ and $\mathrm{CC}$ crude venoms as potential novel complementary or alternative therapies for HNSCC. However, further studies are required to unravel the effect of these venoms on normal cells, fully explore the underlying mechanisms for inhibition of cancer cells and to confirm the more favorable anticancer effect of $\mathrm{CC}$ venom as well as isolation and characterization of the biologically active components within these venoms.

\section{ACKNOWLEDGMENT}

The authors gratefully thank Dr. Aly Fahmy Mohamed Head of International Centre for Advanced Researchers (ICTAR) (Egypt) for his valuable technical advises.

Funding: The study was funded by personal resources to be refunded later by the Ministry of Higher Education, Cairo, Egypt on international publishing. 


\section{Conflicts of Interest:}

The authors declare no conflicts of interest.

\section{REFERENCES}

1. Sanderson R J, and Ironside J A. Squamous cell carcinomas of the head and neck. BMJ. 2002; 325(7368): 822-827. doi: $10.1136 /$ bmj.325.7368.822

2. Kamangar F, Dores G M and Anderson W F. Patterns of cancer incidence, mortality, andprevalence across five continents: defining prioritiesto reduce cancer disparities in different geographicregions of the world. J. Clin. Oncol. 2006; 24, 2137-2150.

3. Sturgis EM, Cinciripini PM. Trends in head and neck cancer incidence in relation to smoking prevalence: an emerging epidemic of human papillomavirus-associated cancers? Cancer. 2007;110:1429-1435.

4. Yan W, Wistuba II, Emmert-Buck MR, Erickson HS. Squamous cell carcinoma - similarities and differences among anatomical sites. Am J Cancer Res. 2011; 1(3): 275-300.

5. Bray F, Ferlay J, Soerjomataram I, Siegel RL, Torre LA, JemalA.Global cancer statistics 2018: GLOBOCAN estimates of incidence and mortality worldwide for 36 cancers in 185 countries. CA Cancer J Clin. 2018 Nov;68(6):394-424. doi: 10.3322/caac.21492.

6. Ibrahim AS, Khaled HM, Mikhail NN, Baraka H, KamelH.Cancer incidence in egypt: results of the national population-based cancer registry program. J Cancer Epidemiol. 2014;2014:437971. doi: 10.1155/2014/437971.

7. Datema FR, Ferrier MB, van der Schroeff MP, Baatenburg de Jong RJ. Impact of comorbidity on short-term mortality and overall survival of head and neck cancer patients. Head Neck. 2010 Jun;32(6):728-36. doi: 10.1002/hed.21245.

8. Demain AL, and Vaishnav P. Natural products for cancer chemotherapy MicrobBiotechnol. 2011; 4(6): 687-699. doi: 10.1111/j.1751-7915.2010.00221.x

9. Munawar A, Ali SA,Akrem A and Betzel C. Snake Venom Peptides: Tools of Biodiscovery. Toxins 2018, 10(11), 474; https://doi.org/10.3390/toxins10110474

10. Li L, Huang J, Lin Y. Snake Venoms in Cancer Therapy: Past, Present and Future. Toxins (Basel). 2018 Aug 29;10(9). pii: E346. doi: 10.3390/toxins 10090346.
11. Shebl RI, Mohamed AF, Ali AE and Amin MA. Cerastescerastes and Viperalebetina Snake Venoms Apoptotic - Stimulating Activity to Human Breast Cancer Cells and Related Gene Modulation. J Cancer SciTher 2012, 4.10 http://dx.doi.org/10.4172/1948-5956.1000161

12. Akef H, Kotb N, Abo-Elmatty D, Salem S. Anti-proliferative Effects of Androctonusamoreuxi Scorpion and CerastescerastesSnakeVenoms on Human Prostate Cancer Cells. J Cancer Prev. 2017 Mar;22(1):40-46. doi: 10.15430/ JCP.2017.22.1.40.

13. Ebrahim K, Vatanpour H, Zare A, Shirazi FH, Nakhjavani M. Anticancer Activity a of Caspian Cobra (Najanajaoxiana) snake Venom in Human Cancer Cell Lines Via Induction of Apoptosis. Iranian Journal of Pharmaceutical Research 2016; 15 (Special issue): 101-112.

14. Ozverel CS, Damm M, Hempel BF, Göçmen B, Sroka R, Süssmuth RD, Nalbantsoy A. Investigating the cytotoxic effects of the venom proteome of two species of the Viperidae family (Cerastescerastes and Cryptelytropspurpureomaculatus) from various habitats. CompBiochemPhysiol C ToxicolPharmacol. 2019 Jun;220:20-30. doi: 10.1016/j. cbpc.2019.02.013.

15. Gouda AS, Elnabarawy NA, Badawy SM. A study of snakebite envenomation cases admitted to egyptian national poisoning center. Acta Med Int 2017;4:34-40

16. El Hakim AE, Gamal-Eldeen AM, Shahein YE, Mansour NM, Wahby AF, Abouelella AM. Purification and characterization of a cytotoxic neurotoxin-like protein from Najahajehaje venom that induces mitochondrial apoptosis pathway. Arch Toxicol. 2011 Aug;85(8):941-52. doi: 10.1007/s00204-010-0631-8.

17. Al-Quraishy S, Dkhil MA, Abdel Moneim AE. Hepatotoxicity and oxidative stress induced by Najahaje crude venom. J Venom Anim Toxins Incl Trop Dis. 2014 Sep 15;20(1):42. doi: 10.1186/1678-9199-20-42.

18. Tohamy AA, Mohamed AF, Abdel Moneim AE, Diab MSM: Biological effects of Najahaje crude venom on the hepatic and renal tissues of mice. J King Saud UnivSci 2014, 26(3):205-212.

19. Zouari-Kessentini R, Luis J, Karray A, Kallech-Ziri O, Srairi-Abid N, Bazaa A, et al. Two purified and characterized phospholipases A2 from Cerastescerastes venom, that inhibit cancerous cell adhesion and migration. Toxicon. 2009 Mar 15;53(4):444-53. doi: 10.1016/j.toxicon.2009.01.003. 
20. Ben-Mabrouk H, Zouari-Kessentini R, Montassar F, Koubaa ZA, Messaadi E, Guillonneau X, et al. CC5 and $\mathrm{CC} 8$, two homologous disintegrins from Cerastescerastes venom, inhibit in vitro and ex vivo angiogenesis. Int J BiolMacromol. 2016 May;86:670-80. doi: 10.1016/j. ijbiomac.2016.02.008.

21. Mitupatum T, Aree K., Kittisenachai S, Roytrakul S, Puthong S, Kangsadalampai $\mathrm{S}$ et al. mRNA expression of Bax, Bcl-2, p53, Cathepsin B, Caspase-3 and Caspase-9 in the HepG2 cell line following induction by a novel monoclonal Ab Hep88 mAb: cross-talk for paraptosis and apoptosis. Asian Pac J Cancer Prev. 2016. 17(2), 703-712.

22. Al-Asmari AK, Riyasdeen A, Al-Shahrani MH, Islam M.Snake venom causes apoptosis by increasing the reactive oxygen species in colorectal and breast cancer cell lines.Onco Targets Ther. 2016 Oct 20;9:6485-6498.

23. Darzynkiewicz Z, Halicka HD, Zhao H.Analysis of Cellular DNA Content by Flow and Laser Scanning Cytometry. AdvExp Med Biol. 2010;676:137-47.

24. Valasek MA, Repa JJ. The power of real-time PCR. AdvPhysiol Educ. 2005 Sep;29(3):151-9.

25. Kakanj M, Ghazi-Khansari M, ZareMirakabadi A, Daraei B, Vatanpour H. Cytotoxic Effect of Iranian Viper alebetina Snake Venom on HUVEC Cells. Iranian journal of pharmaceutical research 2015: IJPR 14 (Suppl), 109-114.

26. Bradshaw MJ, Saviola AJ, Fesler E, Mackessy SP. Evaluation of cytotoxic activities of snake venoms toward breast
(MCF-7) and skin cancer (A-375) cell lines. Cytotechnology 2016;68 (4), 687-700.

27. Nalbantsoy A, Hempel BF, Petras D, Heiss P, Göçmen B, Iğci $\mathrm{N}$ et al. Combined venom profiling and cytotoxicity screening of the Radde'smountain viper (Montiviperaraddei) and Mount Bulgar Viper (Montiviperabulgardaghica) with potent cytotoxicity against human A549 lung carcinoma cells. Toxicon 2017Sep 1;135, 71-83. doi: 10.1016/j. toxicon.2017.06.008.

28. Calderon LA, Sobrinho JC, Zaqueo KD, de Moura AA, Grabner AN, Mazzi MV, et al. Antitumoral Activity of Snake Venom Proteins: New Trends in Cancer Therapy.Biomed Res Int. 2014;2014:203639. doi: $10.1155 / 2014 / 203639$.

29. Long F, Wang T, Jia P, Wang H, Qing Y, Xiong T, He M, Wang X.Anti-Tumor Effects of Atractylenolide-I on $\mathrm{Hu}$ man Ovarian Cancer Cells. Med SciMonit. 2017; 23: 571-579

30. Fouad YA and Aanei C. Revisiting the hallmarks of cancer. Am J Cancer Res. 2017; 7(5): 1016-1036.

31. Wilson TR, Johnston PG, Longley DB. Anti-apoptotic mechanisms of drug resistance in cancer.Curr Cancer Drug Targets. 2009 May;19-307:(3)9.

32. Wlodkowic D, Skommer J, Darzynkiewicz Z. Cytometry of apoptosis. Historical perspective and new advances. ExpOncol. 2012 Oct;34(3):255-62. 